\title{
What Mr Blix should do
}

\section{UN's atomic energy agency has been through a bad patch. Its new director should resurrect its original purpose.}

The International Atomic Energy Agency in Vienna has plainly been scarred by the events of the past year, the Israeli raids on the Iraqi reactor at Tamuz among them. But for most of the year the agency has also been haunted by the unaccustomed difficulty of deciding who should be its new director general. Dr Sigvard Eklund, who until September had held the post for eight years, had not simplified the transition by making no secret of his willingness to serve for a third term: but the agency's governors were also perplexed in choosing between the two candidates on offer - Mr Hans Blix, deputy foreign minister of Sweden and $\mathrm{Mr}$ Domingo Siazon of the Philippines. The difficulty has been largely that of choosing between candidates from developed and developing countrics. Exactly the same problem has more recently cropped up in the United Nations itself. The upshot of six months' heart-searching in Vienna is that $\mathrm{Mr}$ Blix has now taken up the post of director general. But he will probably be challenged again when his term expires four years from now. The danger is that the agency, hitherto almost as free from politics as the World Meteorological Organization, will fall foul of the squabbling to which most other United Nations organizations are prone. $\mathrm{Mr}$ Blix should therefore bend his energies to the insulation of the agency from the petty endemic politics of the United Nations system.

How is this to be accomplished? A sense of history will help. The Vienna agency is the product of President Eisenhower's programme in the 1950s that rejoiced in the slogan "Atoms for peace". Nobody doubted, then, that nuclear power stations would spring up apace in the territories of the nuclear powers, bringing prosperity in their wake: what more natural, even at the height of the Cold War, than that the United States and the Soviet Union should offer to share the benefits of thejr new technology with less fortunate governments? Even in the 1950s, however, people had forgotten that the agency they created had only its name in common with the much grander concept put forward in 1947 , as part of the Baruch plan, of a United Nations agency that would literally be the sole owner and custodian of fissile material. The agency that Mr Blix has inherited is best known as the entity responsible for the administration of the safeguards required of non-nuclear power signatories of the Non-Proliferation Treaty: programmes of technical assistance continue, but on such a modest scale that they can make very little difference to the expectations of non-nuclear states that they will be able to decide for themselves even such simple questions as whether the much disputed benefits of nuclear power apply to them. The unaccustomed quarrelsomeness that has now emerged among the 111 member states at Vienna owes something to the belief that the agency should be doing more to spread such benefits of nuclear power as there are. The discontent is entirely justifiable.

The agency's most urgent need is for a realistic programme for helping developing countries to make sober appraisals of the utility of nuclear reactors. There is a limit to the extent to which they can be fobbed off with technical advice from international consultants on the place of nuclear technology in, say, agriculture. But where, the agency will ask, are the funds with which to support a more ambitious programme? For the time being, the unwillingness of the chief members of the agency to contribute more towards its budget is not its chief impediment.

At frequent intervals in the past two decades, the agency has published assessments of the place of nuclear reactors in the economies of developing countries whose optimism has been matched only by their najvety - and which have nevertheless contributed to the present sense that the major nuclear powers are malevolently keeping nuclear power to themselves. Mr Blix should begin by commissioning a more realistic (and more technical) appraisal of the place of nuclear power in the smaller member states of the agency. He should then go further, for the assessment would almost certainly conclude that, within a decade, a great many smaller states will be able to make good use of the occasional well-sited and well-designed power reactor; he should offer a technical appraisal service for developing countries unable to decide between the claims of rival reactor salesmen.

Naturally, many of the founder members of the agency will object to such proposals. Apprajsals that are too realistic may persuade some customers that the time has not yet come when they should buy. In the long run, however, that can only benefit the reputation of nuclear power and thus of its application. Others will protest that the encouragement of nuclear power can only assist the proliferation of nuclear weapons. The reply is twoedged. First, the involvement of the agency in the provision of civil nuclear power is likely to ensure that the safeguards procedures are effective. Second, the Non-Proliferation Treaty is a bargain in which non-nuclear powers agree to forsake nuclear weapons in return for a promise by the nuclear powers that they will assist with civil development. There is no way in which the nuclear powers can escape the commitment except by abrogating the treaty. Their best course is to help ensure that the safeguards procedures are continually improved.

To this end, $\mathrm{Mr}$ Blix could usefully consider whether the agency should soldier on as an amalgam of an international regulatory agency and a technical assistance organization. There is a strong case for reconstituting the safeguards organization as an independent quasi-judicial entity, perhaps a kind of permanent secretariat of the Non-Proliferation Treaty. Four years from now there will be a review of the working of the treaty. If safeguards are to be reorganized by then, it is not too soon to start. Fortunately, the wind is blowing in the right direction. The United States Administration is ready to loosen its restrictions on the export of reactors, but would find it convenient if the safeguards procedures were at the same time made more explicit. The agency's committee on the security of supply of nuclear materials, set up after the abortive conference in 1980 on the working of the Non-Proliferation Treaty, needs something tangible in which to sink its teeth. And with Mr Blix being a newcomer there is an ideal opportunity for change.

\section{Congress versus cancer}

\section{The US Congress would legislate against cancer. It must be patient.}

Part of the strength of democratically elected bodies, the United States Congress included, is that they are not necessarily bound by the decisions or the prejudices of their predecessors. That, however, is not a sufficient explanation of the way in which the present United States Congress, still less than a year old, seems bent on repudiating jts predecessors' fondness for those agencies in the front line of what many congressmen used to call the "war 